\title{
Features of the design of a telemedicine complex of a wide profile based on FPGA
}

\author{
Valerii Semenets \\ ORCID 0000-0001-8969-2143 \\ Department of Biomedical \\ Engineering \\ Kharkiv National University \\ of Radio Electronics \\ Kharkiv, Ukraine \\ valery.semenets@nure.ua \\ Oleg Zubkov \\ ORCID 0000-0002-8528-6540 \\ Department of Microprocessor \\ Technologies and Systems \\ Kharkiv National University \\ of Radio Electronics \\ Kharkiv, Ukraine \\ oleh.zubkov@nure.ua
}

\author{
Valeriia Chumak \\ ORCID 0000-0002-2403-020X \\ Department of Microprocessor \\ Technologies and Systems \\ Kharkiv National University \\ of Radio Electronics \\ Kharkiv, Ukraine \\ valeriia.chumak@nure.ua \\ Oleksandr Vorgul \\ ORCID 0000-0002-7659-8796 \\ Department of Microprocessor \\ Technologies and Systems \\ Kharkiv National University \\ of Radio Electronics \\ Kharkiv, Ukraine \\ oleksandr.vorgul@nure.ua
}

\author{
Iryna Svyd \\ ORCID 0000-0002-4635-6542 \\ Department of Microprocessor \\ Technologies and Systems \\ Kharkiv National University \\ of Radio Electronics \\ Kharkiv, Ukraine \\ iryna.svyd@nure.uas \\ Natalia Boiko \\ ORCID 0000-0002-7524-729X \\ Department of Microprocessor \\ Technologies and Systems \\ Kharkiv National University \\ of Radio Electronics \\ Kharkiv, Ukraine \\ natalia.boiko@nure.ua
}

\begin{abstract}
The article discusses the relevance of the development of a telemedicine complex for the rehabilitation of athletes for the removal of various biological characteristics and data transmission over a distance. The block diagram of the device being developed is presented. The choice of the FPGA component for solving the problems of digital signal processing has been substantiated.
\end{abstract}

Keywords—FPGA, biological signal, digital signal processing (DSP), medical complex

\section{INTRODUCTION}

In modern society, taking into account the current epidemiological situation caused by COVID-19, telemedicine has become widely used, both in the world and, in particular, in Ukraine. The main purpose of using telemedicine methods is to ensure equal access to medical services of appropriate quality. For example, providing medical care to a patient in cases where distance and time are critical factors. Also, the use of telemedicine will ensure the formation of the integrity of medical information about the health of patients and contributes to the creation of a single medical space. The functional purpose of the telemedicine complex is determined in accordance with the necessary and sufficient requirements for monitoring the patient's condition. And for patients with chronic diseases and the elderly, this is extremely important. Also, the telemedicine complex can be used to monitor the condition of athletes during training, fitness training, rehabilitation and so on.

The rehabilitation process after injuries and fractures is long and difficult. In accordance with this, the rehabilitation program should be specific, and a necessary aspect in the system of complex rehabilitation of athletes is the use of non-drug methods [1]. Based on the importance of using such rehabilitation methods, it is advisable to develop a device for automated control and restoration of body reactions during rehabilitation.

\section{Designing the Structure of A Telemedicine COMPLEX FOR THE REHABILITATION OF ATHLETES}

When analyzing patent searches and products of leading companies, it is urgent to develop a wearable device for recording biological indicators of athletes, which are basic for the restoration of the musculoskeletal system, with subsequent automatic signal processing and data transmission to various devices.

One of the variants of this device implementation "Fig. 1 " may include:
1) Patient.
2) Control unit.
3) Reader.
4) Block of sensors.
5) Signal processing device.
6) Bluetooth interface or NFC interface.
7) Power supply (such as ultra-thin battery).
8) Memory block.

The device, using the sensor unit (4), reads the biological characteristics of a person (1) with which the sensor device comes into contact. Then it transmits the information to the signal processing device (5), which is programmed using a PC. After digitization, the analysis of the data obtained is carried out. The calculation results are stored on a data carrier (8), and during further examination are compared with the initial results to assess the effectiveness of therapeutic measures and adjust the treatment plan. With the help of the wireless data transmission unit (6), the processed biological information is transmitted to the reader (3). The reader can display to the user and / or transmit sensor data to a remote location for further processing. The physician may revise the data or conduct further analysis and use the data or information to assist in treatment. The power supply unit of 
the device (7) ensures the operability of the device and voltage stabilization.

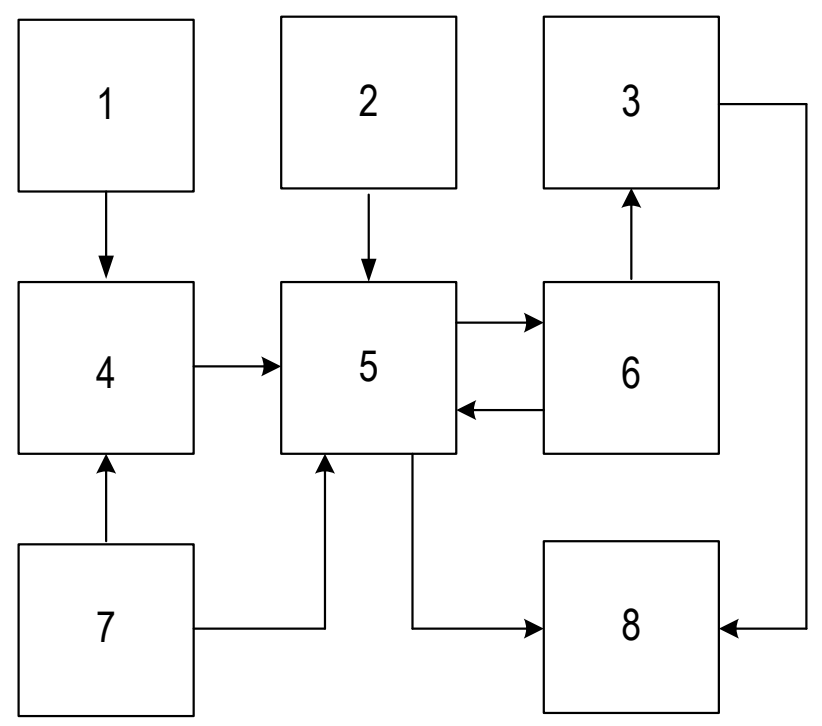

Fig. 1. Block diagram of a portable telemedicine complex.

\section{Selection of a DeVICE For Signal Processing}

Data processing in such systems requires intensive solution of DSP problems and a large number of channels. When choosing a device for signal processing, it is also worth considering a number of parameters:

- $\quad$ system performance;

- energy consumption;

- number of components and form factor of the system;

- the possibility of upgrading the system;

- economic parameters.

Building on the dynamics of healthcare to deliver superior patient care at a lower cost, enhanced imaging, transmission medical imaging and video data there is a tendency to implement tasks on PLC [1].

The peculiarity of the FPGA structure is that each logical block usually has a small number of inputs and one output. This allows more complete use of the internal resources of the microcircuit. At the same time, for FPGAs, the term "maximum clock frequency" refers to the most favorable conditions for chip tracing - all connections are made using short circuits, connected programmable cells are located side by side, the maximum length of accelerated transfer circuits is limited. Unsuccessful routing reduces the allowable clock speed accordingly, but it is very important that after the design is completed, it remains constant [2-6].

A typical logical block is built on the basis of a ROM, in the cells of which the truth table of the combinational circuit is written. The performance of FPGAs on DSP tasks is the higher, the higher the parallelism of processing is used in the algorithm, which accordingly leads to an increase in the amount of logic on the chip. In addition, an important advantage of FPGAs is their ability to provide not only high processing speed, but also continuous processing and stable speed [5-11].

\section{CONCLUSION}

In FPGA, it is also possible to implement processors (for example, a processor on logical cells such as MicroBlaze), however, it is absolutely not necessary to pass the entire stream of processed data through this processor. Moreover, it is recommended to implement high-performance digital processing using DSP resources operating without direct and constant control of the processor [5]. The processor core can perform interface organization, tuning, monitoring, loading coefficients and other operations that are too difficult to implement in hardware. At the same time, a single processor core can control several hundred DSP-blocks of FPGAs, which constantly process the incoming stream even without the participation of the processor. The proposed option for using, in this complex, an FPGA board can be quite advantageous for parallel processing of different biological signals. It seems promising to continue research in the field of FPGA application in medical systems.

\section{REFERENCES}

[1] В.С. Чумак, И.В. Свид. Перспектива использования продукта FPGA в медицинских системах. // XIII Міжнародна науковопрактична конференція магістрантів та аспірантів «Теоретичні та практичні дослідження молодих науковців» (19-22 листопада 2019 року): матеріали конференції. - Харків : НТУ «ХПІ», 2019. - C. 288-289.

[2] I. Svyd, O. Maltsev, L. Saikivska and O. Zubkov, "Review of Seventh Series FPGA Xilinx", I International Scientific and Practical Conference, 2019. doi: 10.35598/mcfpga.2019.008.

[3] "7 Series FPGAs Data Sheet: Overview. Product Specification. DS180 (v2.6) February 27, 2018", Xilinx.com, 2018 [Online].Available:https://www.xilinx.com/support/documentation/da ta_sheets/ds1807Series_Overview.pdf.

[4] В. Чумак, I. Свид. Створення модуля VHDL-опису при проектуванні цифрових систем на ПЛІС в Xilinx ISE Design Suite. // Перспективні напрямки сучасної електроніки, інформаційних і комп'ютерних систем (MEICS-2019). - Дніпро, Дніпровський національний університет імені Олеся Гончара, Кременчук: ПП Щербатих О. В., 2019. - С. 94-95.

[5] I. Svyd, O. Vorgul, V. Semenets, O. Zubkov, V. Chumak and N. Boiko, "Special Features of the Educational Component Design of Devices on Microcontrollers and FPGA", MC\&FPGA-2020, 2020. doi: $10.35598 /$ mcfpga.2020.017.

[6] O. Vorgul, O. Zubkov, I. Svyd and V. Semenets, "Teaching microcontrollers and FPGAs in Quarantine from Coronavirus: Challenges and Prospects", MC\&FPGA-2020, 2020. doi: 10.35598/mcfpga.2020.005.

[7] Z. Oleg, I. Svyd and O. Maltsev, "Features of the use of PID controllers when controlling evaporators", MC\&FPGA-2020, 2020. doi: 10.35598/mcfpga.2020.001.

[8] V. Semenets, "Technical aspects for development laboratory base for learning FPGA and microcontroller systems.", in 10th International Conference The Experience of Designing and Application of CAD Systems in Microelectronics, Lviv-Polyana, Ukraine, 2009, p. 145.

[9] Avrunin O.G. Basics of VDHL language for designing digital devices on FPGA: a textbook. / O.G. Avrunin, T.V. Nosova, V.V. Semenets. Kharkiv: KNURE, 2018. - 196 p.

[10] O. Zubkov, I. Svyd, O. Maltsev and L. Saikivska, "In-circuit Signal Analysis in the Development of Digital Devices in Vivado 2018", I International Scientific and Practical Conference, 2019. Available: 10.35598/mcfpga.2019.003.

[11] V. Soloviev, Architecture of the CPLD of the firm XILINX: CPLD and FPGA of the 7th series. Moscow: Hotline - Telecom, 2016, p. 392. 